\title{
Attention bias for food is independent of restraint in healthy weight individuals : an eye tracking study
}

Citation for published version (APA):

Werthmann, J., Roefs, A., Nederkoorn, C., Mogg, K., Bradley, B. P., \& Jansen, A. (2013). Attention bias for food is independent of restraint in healthy weight individuals : an eye tracking study. Eating Behaviors, 14(3), 397-400. https://doi.org/10.1016/j.eatbeh.2013.06.005

Document status and date:

Published: 01/08/2013

DOI:

10.1016/j.eatbeh.2013.06.005

Document Version:

Publisher's PDF, also known as Version of record

Document license:

Taverne

Please check the document version of this publication:

- A submitted manuscript is the version of the article upon submission and before peer-review. There can be important differences between the submitted version and the official published version of record.

People interested in the research are advised to contact the author for the final version of the publication, or visit the DOI to the publisher's website.

- The final author version and the galley proof are versions of the publication after peer review.

- The final published version features the final layout of the paper including the volume, issue and page numbers.

Link to publication

\footnotetext{
General rights rights.

- You may freely distribute the URL identifying the publication in the public portal. please follow below link for the End User Agreement:

www.umlib.nl/taverne-license

Take down policy

If you believe that this document breaches copyright please contact us at:

repository@maastrichtuniversity.nl

providing details and we will investigate your claim.
}

Copyright and moral rights for the publications made accessible in the public portal are retained by the authors and/or other copyright owners and it is a condition of accessing publications that users recognise and abide by the legal requirements associated with these

- Users may download and print one copy of any publication from the public portal for the purpose of private study or research.

- You may not further distribute the material or use it for any profit-making activity or commercial gain

If the publication is distributed under the terms of Article $25 \mathrm{fa}$ of the Dutch Copyright Act, indicated by the "Taverne" license above, 


\title{
Attention bias for food is independent of restraint in healthy weight individuals-An eye tracking study
}

\author{
Jessica Werthmann ${ }^{\mathrm{a}, *}$, Anne Roefs ${ }^{\mathrm{a}}$, Chantal Nederkoorn ${ }^{\mathrm{a}}$, Karin Mogg ${ }^{\mathrm{b}}$, Brendan P. Bradley ${ }^{\mathrm{b}}$, Anita Jansen ${ }^{\mathrm{a}}$ \\ ${ }^{a}$ Faculty of Psychology \& Neuroscience, Maastricht University, The Netherlands \\ b School of Psychology, University of Southampton, United Kingdom
}

\section{A R T I C L E I N F O}

\section{Article history:}

Received 10 December 2012

Received in revised form 2 May 2013

Accepted 7 June 2013

Available online 15 June 2013

\section{Keywords:}

Attention

Cognitive bias

Eye movements

Food cues

Dietary restraint

BMI

\begin{abstract}
A B S T R A C T
Objective: Restrained eating style and weight status are highly correlated. Though both have been associated with an attentional bias for food cues, in prior research restraint and BMI were often confounded. The aim of the present study was to determine the existence and nature of an attention bias for food cues in healthy-weight female restrained and unrestrained eaters, when matching the two groups on BMI.

Method: Attention biases for food cues were measured by recordings of eye movements during a visual probe task with pictorial food versus non-food stimuli. Healthy weight high restrained $(n=24)$ and low restrained eaters $(n=21)$ were matched on BMI in an attempt to unconfound the effects of restraint and weight on attention allocation patterns.

Results: All participants showed elevated attention biases for food stimuli in comparison to neutral stimuli, independent of restraint status.

Discussion: These findings suggest that attention biases for food-related cues are common for healthy weight women and show that restrained eating (per se) is not related to biased processing of food stimuli, at least not in healthy weight participants.
\end{abstract}

(c) 2013 Elsevier Ltd. All rights reserved.

\section{Introduction}

Attention biases for food have been associated not only with craving, (over)consumption and overweight or obesity (e.g., Nijs, Muris, Euser, \& Franken, 2010; Smeets, Roefs, \& Jansen, 2009; Werthmann et al., 2011) but also with restrained eating (e.g., Hollitt, Kemps, Tiggemann, Smeets, \& Mills, 2010; Veenstra, de Jong, Koster, \& Roefs, 2010). Overweight and obese people typically report higher levels of restraint than healthy-weight people (Johnson, Pratt, \& Wardle, 2011). Therefore, the aim of this study was to test whether restrained eating style, independently of body weight, is associated with an attentional bias for food cues.

Evidence of an attention bias for food in restrained eaters is mixed. For example, minor effects for biased attention for food words in restrained eaters, as assessed by the modified Stroop-paradigm, were reported in meta-analyses (e.g., Brooks, Prince, Stahl, Campbell, \& Treasure, 2011). Yet, the interference effect does not inform about the underlying visual attention processes (Mogg, Bradley, Field, \& De Houwer, 2003). Other studies have used paradigms that can distinguish specific attention processes (i.e., visual search, visual probe and flanker paradigm). Some found that restrained eaters have an attention bias towards high-calorie food cues (Hollitt et al., 2010; Meule, Vögele, \&

\footnotetext{
Corresponding author at: Faculty of Psychology and Neuroscience, P.O. Box 616, 6200 MD Maastricht, The Netherlands. Tel.: + 31433884558 ; fax: + 31433884196.

E-mail address: Jessica.Werthmann@maastrichtuniversity.nl (J. Werthmann).
}

Kübler, 2012), or avoided attending high-calorie food pictures in an exogenous cueing task (Veenstra et al., 2010), or showed no conclusive evidence of an attention bias for food (Ahern, Field, Yokum, Bohon, \& Stice, 2010; Boon, Vogelzang, \& Jansen, 2000; Forestell, Lau, Gyurovski, Dickter, \& Haque, 2012; study 1).

Apart from the large variety of paradigms that have been used to assess attentional bias for high-calorie foods in restrained eaters, an important problem is that typically body weight (as indicated by the body mass index; BMI) and restraint status have been confounded in prior research. Attention biases for food might be primarily associated with weight problems, and might therefore be more related to weight than restraint per se. Thus, there are two competing explanations for the existing evidence of an attentional bias for food in restrained eaters: Restrained eating itself causes the attentional bias, or, alternatively, heightened BMI, typically associated with restraint, is the cause of the attentional bias.

Our first aim was to test whether restrained eating is related to increased attention bias for food, independent of weight status. We isolated the influence of restraint methodologically by keeping BMI constant (within a healthy BMI range) and varying the distribution of restrained eating behaviour. Thus, our study contributes to unconfounding the effects of BMI and restraint on attentional bias for food.

Apart from the question of whether restrained eating style, independently of BMI, affects attentional processing of food cues, a second aim of this study was to explore the direction and duration of the potential attentional bias. Research on attention biases in eating disorders and 
addictions shows that these attention components are differently related to motivational processing of food (or drug) cues (Bradley, Mogg, Wright, \& Field, 2003; Field, Mogg, Zetteler, \& Bradley, 2004; Smeets, Roefs, van Furth, \& Jansen, 2008). It is possible that restrained eaters display attention avoidance of food cues, in an attempt to follow their dieting rules, or that restrained eaters show attentional approach, reflecting high preoccupation with food (Higgs, Rutters, Thomas, Naish, \& Humphreys, 2012; Lowe \& Levine, 2005). Another possibility is that restrained eaters show an approach-avoidance conflict (Papies, Stroebe, \& Aarts, 2008), for example, an initial orientation towards food (automatic approach), followed by diverting attention away from food in later stages of processing (strategic avoidance).

Therefore paradigms that can distinguish between these attentional components are more informative for the question of whether restrained eating is associated with attention avoidance of food cues (e.g. reflecting dieting motivation) or attentional approach towards food cues (e.g. reflecting food pre-occupation or eating enjoyment). In this respect, a meta-analysis recently concluded that eye movement recording is the most sensitive measure for attention biases in the context of addiction because it allows for an unambiguous distinction of specific components of attention allocation processes, and, due to the dynamic character, provides an assessment of change in attention biases over time following stimulus onset (Field, Munafó, \& Franken, 2009).

\section{Method}

\subsection{Participants}

Potential participants were screened on restraint and self-reported BMI $\left(\mathrm{kg} / \mathrm{m}^{2}\right)$ and matched as closely as possible on their self-reported BMI. Female healthy-weight unrestrained $(n=21)$ and restrained eaters $(n=24)$, based on a median-split on their Restraint Scale scores (Herman \& Polivy, 1980) (Mdn = 11; Range $=4-27)$, were included. Four additional participants were tested but excluded because their actual BMI did not meet the inclusion criterion of healthy weight (See Table 1).

Table 1

Characteristics and attention bias scores of restrained and unrestrained eaters.

\begin{tabular}{|c|c|c|c|c|c|c|}
\hline & \multicolumn{2}{|c|}{$\begin{array}{l}\text { Restrained } \\
\text { eaters } \\
(n=24)\end{array}$} & \multicolumn{2}{|c|}{$\begin{array}{l}\text { Unrestrained } \\
\text { eaters } \\
(n=21)\end{array}$} & \multirow[b]{2}{*}{$t(43)$} & \multirow[b]{2}{*}{$p$} \\
\hline & $M$ & $S D$ & $M$ & $S D$ & & \\
\hline RS score & 15.75 & 4.34 & 7.19 & 1.97 & $8.70^{1}$ & $<0.001$ \\
\hline Age & 21.50 & 1.34 & 21.87 & 2.66 & 0.84 & 0.40 \\
\hline BMI & 21.77 & 1.59 & 21.11 & 1.60 & 1.38 & 0.17 \\
\hline Hunger & 47.95 & 20.49 & 47.36 & 28.10 & 0.08 & 0.94 \\
\hline Time since last meal (in min) & 107.67 & 63.80 & 139.29 & 88.15 & 1.39 & 0.17 \\
\hline Gaze direction bias ${ }^{\mathrm{a}}$ & 51.97 & 6.56 & 52.63 & 7.26 & 0.37 & 0.75 \\
\hline Initial gaze duration bias ${ }^{\mathrm{b}}$ & 66.81 & 123.59 & 93.28 & 120.94 & 0.72 & 0.47 \\
\hline Dwell time bias ${ }^{\mathrm{b}}$ & 32.71 & 128.03 & 51.68 & 129.10 & 0.49 & 0.62 \\
\hline Response latency bias ${ }^{\mathrm{b}}$ & 5.99 & 18.87 & 5.57 & 17.48 & 0.08 & 0.94 \\
\hline
\end{tabular}

Note. RS = Restraint Scale (Herman \& Polivy, 1980), BMI = Body Mass Index.

Gaze direction Bias $=\mathrm{N}$ of first fixations on high-calorie food stimuli/( $\mathrm{N}$ of first fixations on high-calorie food stimuli $+\mathrm{N}$ of first fixations on non-food stimuli) $* 100$. Initial gaze duration bias = mean duration of the sum of initial fixations occurring within region of high-calorie food stimuli when initially fixated on - mean duration of the sum of initial fixations occurring within region of non-food stimuli when initially fixated on. Dwell time bias = mean total dwell time on high-calorie food stimuli - mean total dwell time on non-food stimuli. Response latency bias $=$ Mean response latency in congruent trials - mean response latency in incongruent trials.

a In \%.

b In ms.

1 Unequal variances: df were corrected to 32,975, and $t$ and $p$ were reported accordingly.

\subsection{Pictorial visual probe paradigm}

\subsubsection{Overview}

Attention biases for high-calorie food were assessed from concurrent eye movements recording and manual response latencies during a visual probe paradigm with pictures of high-caloric food and nonfood stimuli (for a complete description of this task, see Werthmann et al. (2011). The visual probe paradigm comprised 120 trials ( 80 critical and 40 filler trials) which were divided into two blocks of 60 trials. For critical trials, 20 picture pairs, with high caloric food paired with non-food pictures (musical instruments), were presented four times. Picture pairs on filler trials showed neutral non-food objects, each presented four times. Practice trials also used pictures of common non-food items. Pictures used on filler and practice trials were different from those used for critical trials. Image pairs were the same as those used in Werthmann et al. (2011) and were presented for $2000 \mathrm{~ms}$. Each stimulus was presented equally often on the left and right side of the screen. The position of the probe was equally distributed per stimulus type and appeared equally often on the left and right side of the screen. The order of trials was randomized individually for each participant.

\subsection{Eye movement measurements}

Eye movements were recorded by a desktop mounted Eyelink 1000 system (SR Research, Mississauga, Ontario, Canada) and extracted using Data Viewer (SR Research, Mississauga, Ontario, Canada) exlcuding anticipatory eye movements, gaze fixations in the mid area and filler trials (see Werthmann et al., 2011). Three attention bias scores were calculated: (i) gaze direction bias: the proportion of trials on which the first fixation was directed to a food stimulus versus a non-food stimulus (a score above $50 \%$ indicates a higher proportion of first fixations on food stimuli); (ii) initial gaze duration bias: a measure for early attention maintenance, defined as the difference between the sum of fixations between food and non-food stimuli, before gaze was shifted away from the initially fixated picture (a positive score indicates longer initial gaze on food, than non-food, stimuli), and (iii) gaze dwell time bias: the average total dwell time on food versus non-food stimuli (a positive score indicates a bias towards food stimuli), (e.g., Castellanos et al., 2009; Werthmann et al., 2011).

\subsection{Manual response latencies to probes}

Response times (RTs) were excluded from analyses if they were faster than $200 \mathrm{~ms}$, slower than $2000 \mathrm{~ms}$, and then if they deviated more than 3 SDs from each participant's mean (Mogg, Bradley, Hyare, \& Lee, 1998). RT bias scores were computed by subtracting the mean RT on congruent trials (i.e., when the probe replaced a food image) from the mean RT on incongruent trials (i.e., when the probe replaced the neutral image). A positive bias score indicates an attention bias towards food.

\subsection{Questionnaires}

\subsubsection{Restrained eating}

The Restraint Scale (RS; Herman \& Polivy, 1980) assesses weight concerns, weight fluctuations and self-reported attempts to diet, and was used to identify unrestrained and restrained eaters in this study.

\subsubsection{Hunger}

Subjective hunger was assessed by three $100 \mathrm{~mm}$ visual analogue scales (rating how hungry, how much craving, and how much she thought she could eat) and a compound measure was computed for data analyses. Additionally, the participant indicated the time passed since her last meal and time that would elapse until her next meal. 


\subsection{Procedure}

After informed consent and practice trials, the visual probe task was performed. Afterwards, the participant filled in the RS and hunger scales. Height $(\mathrm{m})$ and weight $(\mathrm{kg})$ were measured. Finally, the participant was debriefed and compensated. The local ethical committee approved the study.

\section{Results}

\subsection{Descriptive statistics}

Restrained and unrestrained eaters did not differ on hunger measures or BMI when they entered the lab (see Table 1), confirming that average BMI was matched between the groups.

\subsection{Attention bias scores}

\subsubsection{Analyses group as a whole}

One sample $t$-tests, comparing gaze direction bias scores against a score of $50 \%$ (which indicates no attention bias), revealed a significant gaze direction bias for food cues in the whole sample $(M=52.28$, $S D=6.83, t(44)=2.24, p=.030$ ). Overall, participants also showed a bias for food stimuli in later visual attention processes, as revealed by one-sample $t$-tests against 0 (indicating no bias), for initial gaze duration bias $(M=79.16, S D=121.71, t(44)=4.36, p<.0001)$; dwell time bias $(M=41.57, S D=127.42, t(44)=2.19, p=.034)$; and RT bias $(M=5.80, S D=18.03, t(44)=2.16, p=.037)$ scores.

\subsubsection{Comparing restrained and unrestrained eaters}

Restrained eaters did not differ from unrestrained eaters on any of the bias scores, as shown by independent $t$-tests (all $t$ 's $<0.72$; all p's $>.47$ ), see Table 1 .

\section{Discussion}

The current study was conducted in an effort to unconfound the effects of restraint and weight-status on attentional bias for food and to examine the exact nature of the hypothesized attentional bias for food. Results indicated that, overall, participants showed increased attention to food stimuli relative to non-food stimuli on all attention bias scores. Moreover, these bias scores were not larger for restrained than unrestrained eaters.

These results suggest that attention biases for food cues are "normal" and apparent in healthy weight women, irrespective of restraint level. The lack of an effect of restraint on attention bias could not be explained by other confounding factors, such as hunger or BMI, as these did not differ between the groups. These results are in line with previous studies that also reported no differences in attention biases for food between restrained and unrestrained eaters (Ahern et al., 2010; Boon et al., 2000; Forestell et al., 2012: study 1 ). Former null results have often been the basis for speculations on whether null findings reflected a lack of attention bias or a zero net effect resulting from the co-occurrence of approach and avoidance processes. The present study did not support these latter speculations, while using an online assessment of eye movements, the most sensitive measure of visual attention currently available (Field et al., 2009).

The present results, however, contrast with findings of previous studies that did report a significant difference in attention bias between restrained and unrestrained eaters (Hollitt et al., 2010; Meule et al., 2012; Overduin, Jansen, \& Louwerse, 1995; Veenstra et al., 2010). The present results suggest a possible reason for the divergence of previous results, namely that unconfounding of weight and restraint (as attempted in the current study) eliminates the formerly observed bias effect. Typically, restrained eating and BMI are highly correlated. Indeed, studies that reported an attention bias observed this bias in restrained eaters who were significantly heavier than unrestrained eaters (e.g. Meule et al., 2012; Veenstra et al., 2010). In combination with the present results, these findings suggest that not restraint per se, but weight problems (i.e., overweight and obesity) could have contributed to previously observed differences between restrained and unrestrained eaters. In line with this, several studies have reported differences in attention biases between healthy weight and overweight or obese participants (Castellanos et al., 2009; Nijs et al., 2010; Werthmann et al., 2011).

In conclusion, restrained eating per se does not contribute to biased attentional processing of food stimuli, at least not within healthy weight females. Given that attention biases for food could be universally present, the relationship between attention biases and actual food intake should be further investigated.

\section{Role of funding sources}

Jessica Werthmann is funded by a PhD fellowship from Maastricht University. The funding source had no role in the study design, the collection, analysis or interpretation of the data.

\section{Contributions}

All authors contributed to the design of the study and writing the manuscript. JW collected data and conducted the data analysis.

\section{Conflict of interest}

None.

\section{Acknowledgements}

We thank Ariane Cuenen for her help in recruiting and testing participants

\section{References}

Ahern, A. L., Field, M., Yokum, S., Bohon, C., \& Stice, E. (2010). Relation of dietary restraint scores to cognitive biases and reward sensitivity. Appetite, 55. http://dx.doi.org/10.1016/j.appet.2010.04.001.

Boon, B., Vogelzang, L., \& Jansen, A. (2000). Do restrained eaters show attention toward or away from food, shape and weight stimuli? European Eating Disorders Review, 8, 51-58. http://dx.doi.org/10.1002/(SICI)1099-0968(200002)8:1<51*AID-ERV306>3.0.CO·2-E.

Bradley, B. P., Mogg, K., Wright, T., \& Field, M. (2003). Attentional bias in drug dependence: Vigilance for cigarette-related cues in smokers. Psychology of Addictive Behaviors, 17(1), 66-72. http://dx.doi.org/10.1037/0893-164X.17.1.66.

Brooks, S., Prince, A., Stahl, D., Campbell, I. C., \& Treasure, J. (2011). A systematic review and meta-analysis of cognitive bias to food stimuli in people with disordered eating behaviour. Clinical Psychology Review, 31, 37-51. http://dx.doi.org/10.1016/ j.cpr.2010.09.006.

Castellanos, E. H., Charboneau, E., Dietrich, M. S., Park, S., Bradley, B. P., Mogg, K., et al. (2009). Obese adults have visual attention bias for food cue images: evidence for altered reward system function. [Article]. International Journal of Obesity, 33(9), 1063-1073. http://dx.doi.org/10.1038/ijo.2009.138.

Eyelink 1000 [Apparatus and software]. (2010). Mississauga. Canada: SR Research Ltd.

Field, M., Mogg, K., Zetteler, J., \& Bradley, B. P. (2004). Attentional biases for alcohol cues in heavy and light social drinkers: the roles of initial orienting and maintained attention. Psychopharmacology, 176(1), 88-93. http://dx.doi.org/10.1007/s00213-0041855-1.

Field, M., Munafó, M. R., \& Franken, I. H. A. (2009). A meta-analytic investigation of the relationship between attentional bias and subjective craving in substance abuse. Psychological Bulletin, 135(4), 589-607. http://dx.doi.org/10.1037/a0015843.

Forestell, C. A., Lau, P., Gyurovski, I. I., Dickter, C. L., \& Haque, S. S. (2012). Attentional biases to foods: The effects of caloric content and cognitive restraint. Appetite, 59(3), 748-754. http://dx.doi.org/10.1016/j.appet.2012.07.006.

Herman, C. P., \& Polivy, J. (1980). Restrained eating. In A. J. Stunkard (Ed.), Obesity (pp. 209-224). Philadelphia: Saunders.

Higgs, S., Rutters, F., Thomas, J. M., Naish, K., \& Humphreys, G. W. (2012). Top down modulation of attention to food cues via working memory. Appetite, 59(1), 71-75. http://dx.doi.org/10.1016/j.appet.2012.03.018.

Hollitt, S., Kemps, E. Tiggemann, M., Smeets, E., \& Mills, J. S. (2010). Components of attentional bias for food cues among restrained eaters. Appetite, 54(2), 309-313. http://dx.doi.org/10.1016/j.appet.2009.12.005.

Johnson, F., Pratt, M., \& Wardle, J. (2011). Dietary restraint and self-regulation in eating behavior. International Journal of Obesity, 36, 665-674. http://dx.doi.org/10.1038/ ijo.2011.156.

Lowe, M. R., \& Levine, A. S. (2005). Eating motives and the controversy over dieting: Eating less than needed versus less than wanted. Obesity Research, 13(5), 797-806. http://dx.doi.org/10.1038/oby.2005.90.

Meule, A., Vögele, C., \& Kübler, A. (2012). Restrained eating is related to accelerated reaction to high caloric foods and cardiac autonomic dysregulation. Appetite, 58, 638-644. http://dx.doi.org/10.1016/j.appet.2011.11.023. 
Mogg, K., Bradley, B. P., Field, M., \& De Houwer, J. (2003). Eye movements to smoking-related pictures in smokers: Relationship between attentional biases and implicit and explicit measures of stimulus valence. Addiction, 98(6), 825-836. http://dx.doi.org/10.1046/j.1360-0443.2003.00392.x.

Mogg, K., Bradley, B. P., Hyare, H., \& Lee, S. (1998). Selective attention to food-related stimuli in hunger: Are attentional biases specific to emotional and psychopathological states, or are they also found in normal drive states? Behaviour Research and Therapy, 36(2), 227-237. http://dx.doi.org/10.1016/S0005-7967(97)00062-4.

Nijs, I. M. T., Muris, P., Euser, A. S., \& Franken, I. H. A. (2010). Differences in attention to food and food intake between overweight/obese and normal-weight females under conditions of hunger and satiety. Appetite, 54(2), 243-254. http://dx.doi.org/ 10.1016/j.appet.2009.11.004.

Overduin, J., Jansen, A., \& Louwerse, E. (1995). Stroop interference and food intake. International Journal of Eating Disorders, 18, 277-285. http://dx.doi.org/10.1002/ 1098-108X(199511)18:3<277::AID-EAT2260180310>3.0.CO;2-3.
Papies, E. K., Stroebe, W., \& Aarts, H. (2008). The allure of forbidden food: On the role of attention in self-regulation. Journal of Experimental Social Psychology, 44(5), 1283-1292. http://dx.doi.org/10.1016/j.jesp.2008.04.008.

Smeets, E., Roefs, A., \& Jansen, A. (2009). Experimentally induced chocolate craving leads to an attentional bias in increased distraction but not in speeded detection. Appetite, 53(3), 370-375. http://dx.doi.org/10.1016/j.appet.2009.07.020.

Smeets, E., Roefs, A., van Furth, E., \& Jansen, A. (2008). Attentional bias for body and food in eating disorders: increased distraction, speeded detection, or both? Behaviour Research and Therapy, 46(2), 229-238. http://dx.doi.org/10.1016/j.brat.2007.12.003.

Veenstra, E. M., de Jong, P. J., Koster, E. H. W., \& Roefs, A. (2010). Attentional avoidance of high-fat food in unsuccessful dieters. Journal of Behavior Therapy and Experimental Psychiatry, 41(3), 282-288. http://dx.doi.org/10.1016/j.jbtep.2010.02.006.

Werthmann, J., Roefs, A., Nederkoorn, C., Mogg, K., Bradley, B. P., \& Jansen, A. (2011) Can(not) take my eyes off it: Attention bias for food in overweight participants Health Psychology, 30, 561-569. http://dx.doi.org/10.1037/a0024291. 